JAMP: Jurnal Adminitrasi dan Manajemen Pendidikan

Volume 4 Nomor 4 Desember 2021, Hal : 364 - 371

Tersedia Online di http://journal2.um.ac.id/index.php/jamp/

ISSN 2615-8574 (online)

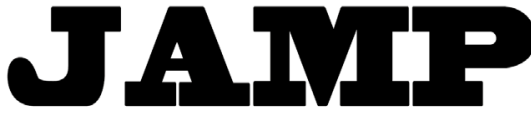

JURNAL ADMINISTRASI DAN MANAJEMEN PENDIDIKAN

\title{
PENGELOLAAN SUMBER DAYA MANUSIA UNTUK MENINGKATKAN KOMITMEN DAN KINERJA ORGANISASI
}

\author{
Titik Hartini
}

\author{
Magister Manajemen Universitas Gajayana Malang \\ Jl. Mertojoyo Blk. L, Merjosari, Kec. Lowokwaru, Kota Malang, Jawa Timur 65144 \\ Email: 123titikhartini@gmail.com No. HP: 085290382563
}

\begin{abstract}
This study aims to analyze and describe the management of human resources, inter-management commitment, and the performance of the administrators of the Student Executive Board (BEM) of the Kertarajasa Buddhist College (STAB) Batu. This research is a qualitative descriptive study using interviews and observations in collecting data from the chairman, vice chairman and 10 administrators of the Student Executive Board (BEM) of the Kertarajasa Buddhist College (STAB) Batu. The results showed that the management of human resources carried out by the Student Executive Board (BEM) of the Kertarajasa Buddhist College (STAB) Batu had been carried out well. The commitment of the management is considered quite good, there are still several obstacles, including differences of opinion and communication that does not go well. As for the performance of the Student Executive Board (BEM) of the Kertarajasa Buddhist College (STAB) Batu, it is considered quite good and active by implementing work programs from each field. Some work programs that cannot be carried out directly due to the Covid-19 pandemic condition, the steps taken are to do it online.
\end{abstract}

Keywords: human reources management;commitment; performance

\begin{abstract}
Abstrak: Penelitian ini bertujuan untuk menganalisis dan mendeskripsikan pengelolaan sumber daya manusia,komitmen antarpengurus, dan kinerja para pengurus Badan Eksekutif Mahasiswa (BEM) Sekolah Tinggi Agama Buddha (STAB) Kertarajasa Batu.Penelitian ini merupakan penelitian deskriptif kualitatif dengan menggunakan metode wawancara dan observasi dalam pengumpulan data dariketua, wakil ketua dan 10 pengurus Badan Eksekutif Mahasiswa (BEM) Sekolah Tinggi Agama Buddha (STAB) Kertarajasa Batu. Hasil penelitian menunjukkan bahwa pengelolaan sumber daya manusia yang dilakukan Badan Eksekutif Mahasiswa (BEM) Sekolah Tinggi Agama Buddha (STAB) Kertarajasa Batu telah dilakukan dengan baik. Komitmen para pengurus dinilai cukup baik meskpiun masih ada beberapa kendala diantaranya perbedaan pendapat dan komunikasi yang tidak berjalan dengan baik. Sedangkan untuk kinerja Badan Eksekutif Mahasiswa (BEM) Sekolah Tinggi Agama Buddha (STAB) Kertarajasa Batu dinilai sudah cukup baik dan aktif dengan melaksanakan programprogram kerja dari setiap bidang. Beberapa program kerja yang tidak dapat dilaksanakan secara langsung dikarenakan adanya kondisi pandemi covid-19maka langkah yang diambil denganmelakukannya secara daring.
\end{abstract}

Kata kunci: pengelolaan sumber daya manusia; komitmen; kinerja

mahasiswa merupakan sumber daya manusia yang memiliki peran aktif dan sebagai faktor utama dalam mempengaruhi kemajuan dan kemunduran organisasi kemahasiswaan. Mahasiswa yang berperan aktif dalam organisasi kemahasiswaan memperoleh pengalaman baru secara langsung melalui praktik nyata yang diwujudkan dalam berbagai kegiatan atau program kerja. Sekolah Tinggi Agama Buddha (STAB) Kertarajasa Batu memiliki organisasi kemahasiswaan dan pembinanya langsung berada di bawah wakil ketua bidang kemahasiswaan yaitu Badan Eksekutif Mahasiswa (BEM). Sebagai organisasi 
kemahasiswaan memiliki anggota dan pengurus yang memiliki keragaman maka Badan Eksekutif Mahasiswa (BEM) Sekolah Tinggi Agama Buddha (STAB) Kertarajasa Batu membutuhkan manajemen yang baik.

Arifin (2013) menyebutkan bahwa secara umum, proses pengelolaan sumber daya manusia dalam suatu organisasi meliputi membuat struktur organisasi, melakukan analisis jabatan (job analysis), analisis uraian tugas (job description), merumuskan rencana permintaan karyawan (man poser planning), menghitung analisis beban kerja (work load analysis), dan proses pengembangan (people development). Dalam proses pengelolaan sumber daya manusia juga memiliki prinsip-prinsip dalam pelaksanaanya. Hal ini disebutkan oleh Sunyoto (2013) bahwa terdapat 3 prinsip yaitu berorientasi pada pelayanan, membangun kesempatan terhadap sumber daya manusia untuk berperan aktif dalam organisasi, dan mampu menemukan jiwa interpreneur sumber daya manusia organisasi yang menginginkan adanya akses ke seluruh sumber daya manusia dalam organisasi.

Berdasarkan observasi yang telah dilakukan ditemukan bahwa beberapa pengurus Badan Eksekutif Mahasiswa (BEM) Sekolah Tinggi Agama Buddha (STAB) Kertarajasa Batu dinilai masih memiliki komitmen rendah sehingga hal ini dapat berdampak pada kinerja. Menurut hasil penelitian yang telah dilakukan oleh Hidayaturrahman (2015) dijelaskan bahwa komitmen yang rendah ini disebabkan kurangnya self-interest dari para pengurus. Selain itu, menurut Sugiyanto (2015) juga disebutkan bahwa tanpa adanya komitmen yang kuat dari para pengurus maka organisasi tersebut tidak dapat berjalan dengan baik bahkan tidak dapat bertahan. Kinerja dari para pengurus Badan Eksekutif Mahasiswa (BEM) Sekolah Tinggi Agama Buddha (STAB) Kertarajasa Batu dari komitmen yang terlihat masih terkendala untuk bekerja sama dalam mewujudkan tujuan yang telah ditetapkan.

Komitmen yang dimiliki para pengurus terhadap Badan Eksekutif Mahasiswa (BEM) Sekolah Tinggi Agama Buddha (STAB) Kertarajasa Batu merupakan salah satu faktor penting dalam bekerja. Busro (2018) menjelaskan bahwa dari komitmen karyawan terhadap organisasi dalam hal bekerja sangatlah menentukan dalam pencapaian tujuan yang telah ditetapkan. Dari komitmen para karyawan ini sangatlah menentukan keberhasilan dalam pengelolaan organisasi. Hal ini juga berlaku pada Badan Eksekutif Mahasiswa (BEM) Sekolah Tinggi Agama Buddha (STAB) Kertarajasa Batu untuk tetap memperhatikan dengan baik melalui pengelolaan sumber daya manusia sehingga dapat meningkatkan komitmen dan kinerja para pengurus.

Seperti hasil penelitian yang telah dilakukan oleh Sutoro (2020) menunjukkan bahwa kinerja dicapai melalui komitmen dan motivasi. Hasil temuan ini juga menegaskan bahwa komitmen memiliki peran penting dalam mewujudkan kinerja dan didukung dengan variabel lainnya seperti motivasi, disiplin, kompensasi, dan lingkungan. Penelitian ini memiliki pebedaan dengan beberapa penelitian yang telah dilakukan sebelumnya yaitu terletak pada variabel penelitian yang digunakan. Seperti penelitian yang telah dilakukan oleh Heriyanti (2020) yang menunjukkan bahwa pengembangan sumber daya manusia melalui motivasi dilakukan dengan tiga cara yaitu pelatihan, pemberian insentif, dan reward. Dari ketiga cara tersebut memberikan dampak pada peningkatan kinerja yang dialami setelah adanya pengembangan sumber daya manusia. Jika pada penelitian yang dilakuakn Heriyanti (2020) tentang pengembangan sumber daya manusia melalui motivasi untuk meningkatkan kinerja maka penelitian ini lebih memfokuskan pada pengelolaan sumber daya manusia Badan Eksekutif Mahasiswa (BEM) Sekolah Tinggi Agama Buddha (STAB) Kertarajasa dan menganalisis komitmen serta kinerja para pengurus.

\section{METODE}

Penelitian ini merupakan penelitian deskriptif kualitatif yang mana untuk memperoleh data di lapangan menggunakan wawancara dan observasi kepada para informan yaitu ketua, wakil ketua dan 10 pengurus Badan Eksekutif Mahasiswa (BEM) Sekolah Tinggi Agama Buddha (STAB) Kertarajasa Batu. Data yang sudah diperoleh kemudian dianalisis dengan menggunakan metode analisis dari Miles dan Huberman yang terdiri dari pengumpulan data, reduksi data, penyajian data, dan penarikan kesimpulan. Pada penelitian ini dalam memeriksa keabsahan data digunakan triangulasi sumber. Metode triangulasi 
sumber untuk memperoleh keabsahan data dalam penelitian tentang pengelolaan sumber daya manusia untuk meningkatkan komitmen dan kinerja organisasi yaitu dengan melakukan pengecekan data yang telah diperoleh melalui beberapa sumber. Data yang telah diperoleh dari beberapa sumber yaitu ketua, wakil ketua, dan pengurus Badan Eksekutif Mahasiswa (BEM) Sekolah Tinggi Agama Buddha (STAB) Kertarajasa Batu kemudian dideskripsikan, dikategorisasikan dalam pandangan yang sama dan berbeda, serta mana yang lebih spesifik dari sumber data tersebut.

\section{HASIL}

Keragaman para pengurus Badan Eksekutif Mahasiswa (BEM) Sekolah Tinggi Agama Buddha (STAB) Kertarajasa Batu berdasarkan pernyataan dari ketua umum menjelaskan bahwa hal ini menjadi poin positif dalam menyatukan para pengurus dengan keterampilan dari setiap daerah dengan tradisi dan budaya yang berbeda. Hal positif lainnya yaitu para pengurus Badan Eksekutif Mahasiswa (BEM) Sekolah Tinggi Agama Buddha (STAB) Kertarajasa dapat belajar untuk saling menghormati antarpengurus dan belajar bertoleransi serta belajar budaya dari masing-masing daerah. Sebagian besar pengurus Badan Eksekutif Mahasiswa (BEM) Sekolah Tinggi Agama Buddha (STAB) Kertarajasa merupakan biarawan dan biarawati sehingga harus tetap menjaga perilaku sesama pengurus baik di depan maupun di belakang. Sehingga dari sikap ini dapat membuat para pengurus untuk tetap saling menghormati dan menciptkan kerukunan serta ketiada-cekcokan.

Selain beberapa dampak positif dari keragaman dari para pengurus (BEM) Sekolah Tinggi Agama Buddha (STAB) Kertarajasa juga memiliki dampak negatif yaitu komunikasi diantara para pengurus kurang berjalan secara maksimal dan beberapa kali sering terjadi miskomunikasi. Hal ini disampaikan oleh salah satu pengurus yang menyatakan masih kesulitan melakukan komunikasi dengan anggota bidangnya. Sehingga Badan Eksekutif Mahasiswa (BEM) Sekolah Tinggi Agama Buddha (STAB) Kertarajasa mengambil langkah yaitu dengan menggunakan bahasa Indonesia dalam berkomunikasi antarpengurus.

Berkaitan dengan keragaman para pengurus Badan Eksekutif Mahasiswa (BEM) Sekolah Tinggi Agama Buddha (STAB) Kertarajasa Batu maka dalam proses pengelolaan sumber daya manusia telah dilakukan dengan menerapkan langkah-langkah yang telah ditetapkan. Berdasarkan hasil wawancara dengan wakil ketua II dijelaskan bahwa sebagai sebuah organisasi maka menjadi tempat atau wadah untuk membangun sumber daya manusia dengan membuat program kerja masing-masing bidang baik dalam jangka pendek maupun panjang.

Hal ini juga didukung dengan hasil wawancara dengan wakil ketua I yang menyatakan bahwa Badan Eksekutif Mahasiswa (BEM) Sekolah Tinggi Agama Buddha (STAB) Kertarajasa Batu untuk pengelolaan sumber daya manusia tetap berpedoman pada tujuan intinya yaitu berupaya untuk sumber daya manusia yang dimiliki Badan Eksekutif Mahasiswa (BEM) Sekolah Tinggi Agama Buddha (STAB) Kertarajasa Batu semakin berdaya dan berkualitas di bidangnya masing-masing. Ketua umum menjelaskan bahwa untuk meningkatkan kemampuan dan keterampilan dari para pengurus yaitu pertama, mengadakan pelatihan dasar - dasar kepemimpinan. Kedua yang dilakukan Badan Eksekutif Mahasiswa (BEM) Sekolah Tinggi Agama Buddha (STAB) Kertarajasa Batu adalah menyatukan langkah bersama dalam satu misi dan satu tujuan untuk kedepannya. Hal ini bisa dilihat dari kerjasama para pengurus dalam menjalankan program kerja masing-masing bidang.Yang ketiga adalah dengan menyediakan fasilitas pendukung bagi para pengurus untuk mendukung kegiatan pada setiap bidang.

Langkah awal dalam proses pengelolaan sumber daya manusia pada Badan Eksekutif Mahasiswa (BEM) Sekolah Tinggi Agama Buddha (STAB) Kertarajasa Batu adalah dengan pembuatan sturktur organisasi. Dari pembuatan struktur organisasi ini para pengurus dapat mengetahui tugas dan tanggung jawab yang dilakukan demi pencapaian tujuan yang telah ditetapkan atau lebih tepatnya dilakukan analisis jabatan dan analisis deksirpsi pekerjaan (job description analysis). Badan Eksekutif Mahasiswa (BEM) Sekolah Tinggi Agama Buddha (STAB) Kertarajasa Batu dalam upayanya untuk meningkatkan pengelolaan sumber daya manusia adalah dengan memberikan kompensasi berupa barang seperti mug, gantungan kunci, pin, dan sertifikat kepada para pengurus atas pencapaian kinerjanya. 
Dari pengelolaan sumber daya manusia, dalam hal ini adalah para pengurus Badan Eksekutif Mahasiswa (BEM) Sekolah Tinggi Agama Buddha (STAB) Kertarajasa Batu tetap memperhatikan juga pengelolaan komitmen para pengurus dengan baik. Berdasarkan hasil wawancara dengan wakil ketua II dijelaskan bahwa dari pihak Badan Eksekutif Mahasiswa (BEM) Sekolah Tinggi Agama Buddha (STAB) Kertarajasa Batu tetap memberikan arahan kepada para pengurus yang dinilai masih memiliki komitmen rendah. Yang dimaksudkan dengan komitmen rendah disini adalah para pengurus dalam memberikan kontribusi untuk pelaksanaan kegiatan-kegiatan dinilai masih bersikap kurang peduli. Meskipun hal ini tidak terjadi kepada semua pengurus tetapi hanya ada satu atau dua orang yang masih memiliki komitmen rendah.

Tetapi berdasarkan hasil wawancara dengan beberapa pengurus Badan Eksekutif Mahasiswa (BEM) Sekolah Tinggi Agama Buddha (STAB) Kertarajasa Batu bahwa komitmen antar para pengurus dinilai sudah cukup baik. Hal ini terlihat dari kerja sama dalam menjalankan kegiatan. Dalam menjalankan kegiatan tersebut tidak jarang terjadi perselisihan dikarenakan perbedaan pemikiran atau pendapat. Perbedaan ini tidak menjadi penghambat bagi para pengurus untuk tetap bekerjasama dan berkontribusi untuk kemajuan Badan Eksekutif Mahasiswa (BEM) Sekolah Tinggi Agama Buddha (STAB) Kertarajasa Batu.

Salah satu faktor yang memengaruhi komitmen para pengurus Badan Eksekutif Mahasiswa (BEM) Sekolah Tinggi Agama Buddha (STAB) Kertarajasa Batu yaitu adanya keragaman. Jadi berdasarkan hasil observasi di lapangan tentang keragaman para pengurus maka komitmen para pengurus cenderung tinggi apabila berasal dari satu daerah. Hal ini disebabkan para pengurus merasa adanya kecocokan antar satu dengan yang lain. Hal yang dapat dilakukan oleh Badan Eksekutif Mahasiswa (BEM) Sekolah Tinggi Agama Buddha (STAB) Kertarajasa Batu dalam meningkatkan komitmen antarpengurus yang memiliki keragaman seperti yang disampaikan wakil ketua I dan II dalam wawancara yaitu dengan mengadakan rapat-rapat, baik rapat bulanan atau rapat-rapat untuk membahas suatu kegiatan.Sehingga ini menjadi satu kekuatan untuk mengurangi adanya pengunduran diri dan meningkatkan produktivitas dalam berkarya dalam kemajuan Badan Eksekutif Mahasiswa (BEM) Sekolah Tinggi Agama Buddha (STAB) Kertarajasa Batu.

Langkah selanjutnya yang dilakukan Badan Eksekutif Mahasiswa (BEM) Sekolah Tinggi Agama Buddha (STAB) Kertarajasa Batu dalam meningkatkan komitmen para pengurus adalah dengan memberikan kepercayaan dalam melaksanakan kegiatan yang menjadi tanggung jawab masing-masing bidang. Badan Eksekutif Mahasiswa (BEM) Sekolah Tinggi Agama Buddha (STAB) Kertarajasa Batu memiliki kepercayaan kepada para pengurus yang masing-masing bidang memiliki ketua koordinator dalam melakukan kerjasama untuk melaksanakan setiap program kerja.Selain kepercayaan yang diberikan kepada para pengurus untuk menjalankan program kerja yang telah direncanakan juga memberikan kesempatan bagi para pengurus untuk berpartisipasi dalam pengambilan keputusan terhadap masa depan Badan Eksekutif Mahasiswa (BEM) Sekolah Tinggi Agama Buddha (STAB) Kertarajasa Batu itu sendiri.

Hasil penelitian tentang komitmen para pengurus Badan Eksekutif Mahasiswa (BEM) Sekolah Tinggi Agama Buddha (STAB) Kertarajasa Batu yang terlihat dari kerja sama dan kontribusi dalam membantu pelaksanaan kegiatan ini sejalan dengan Yulistina (2017) yang terkait komitmen mahasiswa dalam berorganisasi pada Lembaga Pengembangan Tilawatil Qur'an dan Dakwah di UIN Raden Fatah Palembang. Yang mana komitmen mahasiswa terlihat dari kontribusi pada saat mengajar, melakukan hal yang diperintahkan, dan membantu ketika ada acara. Hal ini juga terlihat dari komitmen para pengurus Badan Eksekutif Mahasiswa (BEM) Sekolah Tinggi Agama Buddha (STAB) Kertarajasa Batu dalam memberikan kontirbusi pada saat melaksanakan berbagai kegiatan dalam program kerja masing-masing bidang.

Sehingga dengan adanya komitmen para pengurus Badan Eksekuitf Mahasiswa (BEM) Sekolah Tinggi Agama Buddha (STAB) Kertarajasa Batu dapat membantu dalam peningkatan kinerja. Berdasarkan hasil wawancara dengan para pengurus bahwa penilaian terhadap kinerja mereka ada yang aktif dan bagus serta cukup baik apabila dibandingkan dengan kepengurusan Badan Eksekutif 
Mahasiswa (BEM) Sekolah Tinggi Agama Buddha (STAB) Kertarajasa Batu periode sebelumnya. Hal ini dikarenakan dapat melaksanakan program-program kerja yang telah direncanakan dengan baik.

Beberapa pengurus Badan Eksekutif Mahasiswa (BEM) Sekolah Tinggi Agama Buddha (STAB) Kertrajasa Batu merasa puas dengan kinerja yang telah dilakukan. Tetapi masih ada juga beberapa pengurus yang merasa kurang puas dengan kinerjanya. Hal ini disampaikan oleh ketua bidang koordinator bidang umum yang masih kurang puas dengan kinerjanya yang dikarenakan beberapa program kerja yang telah direncanakan belum berjalan sepenuhnya dan masih disibukkan dengan kegiatan perkuliahan dan tugas-tugas kuliah sehingga membuat kinerja para pengurus tidak maksimal.

Beberapa kendala kinerja yang dihadapi para pengurus Badan Eksekutif Mahasiswa (BEM) Sekolah Tinggi Agama Buddha (STAB) Kertarajasa yaitu pada saat ini yang masih terjadi pandemi covid-19, waktu pelaksanaan kegiatan bersamaan dengan jadwal perkuliahan, dan beberapa kali sering terjadi miskomunikasi antara ketua dan pengurus. Sehingga berkenaan dengan program kerja yang tidak dapat dilaksanakan secara langsung dikarenakan adanya covid-19 maka langkah yang diambil Badan Eksekutif Mahasiswa (BEM) Sekolah Tinggi Agama Buddha (STAB) Kertarajasa Batu yaitu dengan melaksanakan beberapa kegiatan seperti seminar, dialog antar Badan Eksekutif Mahasiswa (BEM) Sekolah Tinggi Agama Buddha (STAB) lain yang dilakukan secara daring.

Untuk meningkatkan kinerja para pengurus Badan Eksekutif Mahasiswa (BEM) Sekolah Tinggi Agama Buddha (STAB) Kertarajasa Batu maka berdasarkan hasil wawancara dengan ketua umum yaitu dengan memberikan kebebasan tetapi tetap diberikan pengarahan dan pengawasan, memberikan masukan, arahan, dan motivasi, serta mendengarkan masukan dan saran dari para pengurus demi kemajuan Badan Eksekutif Mahasiswa (BEM) Sekolah Tinggi Agama Buddha (STAB) Kertarajasa Batu.

\section{PEMBAHASAN}

Badan Eksekutif Mahasiswa (BEM) Sekolah Tinggi Agama Buddha (STAB) Kertarajasa Batu merupakan organisasi yang berorientasi pada kegiatan-kegiatan sosial (sosial oriented). Hal ini dapat dilihat dari program kerja pada masing-masing bidang dalam melakukan pembinaan kepada umat Buddha khususnya di Malang Raya dan kegiatan yang bertujuan untuk menambah wawasan kepada seluruh mahasiswa Sekolah Tinggi Agama Buddha (STAB) Kertarajasa Batu. Jadi berdasarkan analisis data dapat diperoleh beberapa hal yaitu

Pertama, beberapa hal yang dilakukan dalam pengelolaan sumber daya manusia oleh Badan Eksekutif (BEM) Sekolah Tinggi Agama Buddha (STAB) Kertarajasa Batu yaitu dengan membuat struktur organisasi untuk mengetahui tugas dan tanggung jawab masing-masing bidang, menyusun perencanaan demi tercapainya visi, misi, dan tujuan yang telah ditetapkan dalam bentuk program kerja masing-masing bidang, meningkatkan kemampuan dan keterampilan para pengurus dengan mengadakan unit kegiatan mahasiswa yang diselenggarakan oleh Badan Eksekutif Mahasiswa (BEM) Sekolah Tinggi Agama Buddha (STAB) Kertarajasa Batu maupun oleh organisasi lain, dan memberikan penghargaan kepada para pengurus dengan kinerja yang baik.

Sehingga hal ini sejalan dengan penelitian yang telah dilakukan oleh Utamy (2020) bahwa implementasi manajemen sumber daya manusia di SMK Negeri Lais telah terlaksana dengan baik, ditandai dengan adanya penyusunan perencanaan sumber daya manusia, perekrutan sumber daya manusia yang profesionalisme dan transparan, pelaksanaan seleksi sumber daya manusia cukup profesional, pelaksanaan orientasi dan penempatan kerja yang memperhatikan kebutuhan sekolah dan kompetensi guru/karyawan, pelaksanaan pelatihan dan pengembangan yang terencana, dan penilaian kinerja. Tetapi masih memiliki faktor penghambat dalam implementasi manajemen sumber daya manusia yaitu kurangnya kesejahteraan guru dan pegawai honorer, kurangnya kejelasan karir, dan penjaminan mutu.

Para pengurus Badan Eksekutif Mahasiswa (BEM) Sekolah Tinggi Agama Buddha (STAB) Kertarajasa Batu memiliki kinerja yang baik dan dapat memberikan kepuasan bagi mereka. Berdasarkan hasil penelitian dari Afuan (2021) menyatakan bahwa kepuasan kerja menjadi suatu hal yang sudah pasti 
diharapkan oleh setiap pegawai dikarenakan kepuasan menjadi cerminan kebahagiaan yang dirasakan atas pekerjaan yang telah dilakukan. Sehingga dari kepuasan kinerja para pengurus dapat meningkatkan komitmen dalam melakukan kinerja yang menjadi tanggungjawab dan program kerja dari setiap bidang.

Dalam hal pengelolaan sumber daya manusia yang dilakukan Badan Eksekutif Mahasiswa (BEM) Sekolah Tinggi Agama Buddha (STAB) Kertarajasa Batu telah dilakukan dengan baik. Dari hasil penelitian yang telah diperoleh menunjukkan bahwa komitmen dan kinerja para pengurus sudah sangat baik. Penelitian ini sejalan dengan hasil penelitian dari Haryanto (2020) yang menyatakan bahwa pengembangan sumber daya manusia memberikan dampak pada komitmen dan kinerja pegawai Dinas Sosial Kabupaten Magetan.

Berikutnya, dengan adanya keragaman sehingga menjadi salah satu faktor dalam menjalin komitmen dan kinerja para pengurus Badan Eksekutif Mahasiswa (BEM) Sekolah Tinggi Agama Buddha (STAB) Kertarajasa Batu. Dengan demikian, langkah yang diambil Badan Eksekutif Mahasiswa (BEM) Sekolah Tinggi Agama Buddha (STAB) Kertarajasa Batu adalah dengan menerapkan sikap toleransi, menggunakan bahasa Indonesia ketika melakukan komunikasi antar pengurus dan tidak ada diskriminasi terhadap para pengurus.

Sedangkan penilaian terhadap kinerja Badan Eksekutif Mahasiswa (BEM) Sekolah Tinggi Agama Buddha (STAB) Kertarajasa Batu dinilai baik, maju, dan aktif dibandingkan dengan periode 2018/2020. Meskipun saat ini beberapa program kerja yang telah direncanakan tidak dapat dilaksanakan secara maksimal bahkan tidak berjalan dikarenakan adanya pandemi Covid-19. Sehingga hal ini menjadi penghambat dalam bekerja dan menyebabkan ketidakpuasanpara pengurus. Langkah yang diambil untuk tetap melaksanakan program kerja yang telah ditetapkan adalah dengan melaksanakan kegiatan secara daring.

Berikut ini hasil kinerja Badan Eksekutif Mahasiswa (BEM) Sekolah Tinggi Agama Buddha (STAB) Kertarajasa Batu selama 4 periode (2014 - 2020):

Tabel 1. Kinerja Badan Eksekutif Mahasiswa (BEM) Sekolah Tinggi Agama Buddha (STAB) Kertarajasa Batu Periode 2014 - 2020

\begin{tabular}{|c|c|c|}
\hline No & Masa Jabatan/Periode & Pencapaian (Goal) \\
\hline 1 & $2014 / 2016$ & $\begin{array}{l}\text { Kinerja Badan Esekutif Mahasiswa (BEM) Sekolah Tinggi } \\
\text { Agama Buddha (STAB) Kertarajasa Batu dinilai baik, maju dan } \\
\text { berhasil. Banyak kegiatan yang dapat dilaksanakan dengan baik, } \\
\text { seperti lomba karya ilmiah yang pertama kali dengan hadiah bagi } \\
\text { pemenang yang sangat menarik, kegiatan pembinaan Umat buddha } \\
\text { Malang Raya yang berjalan secara rutin tiap minggu, kegiatan } \\
\text { kerja bakti di lingkungan kampus yang berjalan dengan lancar } \\
\text { setiap akhir bulan. Sehingga berdasarkan laporan kinerja dikatakan } \\
\text { tercapai maksimal. }\end{array}$ \\
\hline 2 & $2017 / 2018$ & $\begin{array}{l}\text { Kinerja Badan Eksekutif Mahasiswa (BEM) Sekolah Tinggi } \\
\text { Agama Buddha (STAB) Kertarajasa Batu pada periode ini dinilai } \\
\text { kurang maksimal. Hal ini dikarenakan beberapa kegiatan belum } \\
\text { terlaksana secara baik selama satu tahun. }\end{array}$ \\
\hline 3 & $2018 / 2020$ & $\begin{array}{l}\text { Kinerja Badan Eksekutif Mahasiswa (BEM) Sekolah Tinggi } \\
\text { Agama Buddha (STAB) Kertarajasa Batu sedikit terkendala. Hal } \\
\text { ini disebabkan kurang aktifnya para pengurus Badan Eksekutif } \\
\text { Mahasiswa dalam berkontribusi untuk kegiatan-kegiatan yang } \\
\text { dilaksanakan dikarenakan kurang hubungan yang kurang baik dan } \\
\text { terkendala komunikasi. }\end{array}$ \\
\hline 4 & $2020 / 2022$ & $\begin{array}{l}\text { Kinerja Badan Eksekutif Mahasiswa (BEM) Sekolah Tinggi } \\
\text { Agama Buddha (STAB) Kertarajasa Batu pada tahun ini dinilai } \\
\text { cukup baik dan aktif,meskipun masih terkendala dengan adanya } \\
\text { pandemi Covid-19. }\end{array}$ \\
\hline
\end{tabular}

Sumber: Peneliti (2020) 
Jadi berdasarkan tabel 1 tentang kinerja Badan Eksekutif Mahasiswa (BEM) Sekolah Tinggi Agama Buddha (STAB) Kertarajasa pada periode 2020/2022 beberapa program kerja setiap bidang masih terkendala dengan adanya pandemi covid-19. Langkah yang diambil adalah melaksanakan kegiatan seperti seminar yang dilaksanakan secara daring dan diikuti oleh mahasiswa.

Dengan demikian pengelolaan terhadap sumber daya manusia yang ada pada Badan Eksekutif Mahasiswa (BEM) Sekolah Tinggi Agama Buddha (STAB) Kertarajasa Batu dilakukan dengan baik untuk meningkatkan komitmen dan kinerja para pengurus. Hal ini dilakukan dengan mengadakan rapat bersama, memberikan kepercayaan dan kebebasan kepada para pengurus untuk berkarya, dan memberikan penghargaan kepada para pengurus atas pencapaian kinerja yang baik. Para pengurus yang telah bekerja dengan baik dapat memberikan kepuasan bagi mereka dan untuk tetap terus meningkatkan kinerjanya demi kemajuan Badan Eksekutif Mahasiswa (BEM) Sekolah Tinggi Agama Buddha (STAB) Kertarajasa Batu. Yang mana hal ini juga relevan dengan hasil penelitian dari Ferum Mahendra Pranita (2017) yang menyatakan bahwa kepuasan memberikan dampak dalam kinerja setiap individu.

\section{SIMPULAN DAN SARAN}

\section{Simpulan}

Berdasarkan hasil penelitian yang telah dilakukan mengenai pengelolaan sumber daya manusia untuk meningkatkan komitmen dan kinerja Badan Eksekutif Mahasiswa (BEM) Sekolah Tinggi Agama Buddha (STAB) Kertarajasa Batu maka dapat diambil kesimpulan sebagai berikut:

Proses pengelolaan sumber daya manusia pada Badan Eksekutif Mahasiswa (BEM) Sekolah Tinggi Agama Buddha (STAB) Kertarajasa Batu telah dilakukan dengan baik. Hal ini dilakukan oleh Badan Eksekutif Mahasiswa (BEM) Sekolah Tinggi Agama Buddha (STAB) Kertarajasa Batu yang diawali dengan proses rekrutmen dan seleksi, penempatan posisi jabatan, dan penetapan tugas dan tanggungjawab dari masing-masing bidang.Komitmen para pengurus Badan Eksekutif Mahasiswa (BEM) Sekolah Tinggi Agama Buddha (STAB) Kertarajasa Batu dinilai sudah terjalin cukup baik, terlihat dari kontribusi dan kerja sama dalam membantu pelaksanaan kegiatan.Kinerja Badan Eksekutif Mahasiswa (BEM) Sekolah Tinggi Agama Buddha (STAB) Kertarajasa Batu periode 2020/2022 dinilai baik dan sangat aktif dalam mengadakan kegiatan-kegiatan. Meskipun beberapa kegiatan dari masingmasing bidang belum dapat terlaksana maksimal dikarenakan pandemi covid-19 maka langkah yang diambil oleh Badan Eksekutif Mahasiswa (BEM) Sekolah Tinggi Agama Buddha (STAB) Kertarajasa Batu adalah melaksanakan kegiatan yang dapat dilakukan secara daring.

\section{Saran}

Berdasarkan hasil penelitian yang telah diperoleh peneliti maka beberapa saran yang dapat diberikan untuk Badan Eksekutif Mahasiswa (BEM) Sekolah Tinggi Agama Buddha (STAB) Kertarajasa Batu yaitu BEM Sekolah Tinggi Agama Buddha (STAB) Kertarajasa Batu sebagai organisasi kemahasiswaan dengan para pengurus adalah mahasiswa maka tetap harus membangun komunikasi yang efisien, efektif, dan strategis antar pengurus dan anggota, Badan Eksekutif Mahasiswa (BEM) Sekolah Tinggi Agama Buddha (STAB) Kertarajasa Batu harus tetap menjaga dan meningkatkan pengelolaan sumber daya manusia yang dimiliki demi kemajuan dan tercapainya tujuan yang telah ditetapkan, memberikan motivasi dan arahan kepada para pengurus secara berkesinambungan sehingga dapat meningkatkan kinerja dalam menjalankan program kerja yang telah disusun, dan melaksanakan program kerja dari setiap bidang yang belum terlaksana dengan tetap melakukan kerjasama yang baik terhadap kemajuan Badan Eksekutif Mahasiswa (BEM) Sekolah Tinggi Agama Buddha (STAB) Kertarajasa Batu demi tercapainya tujuan yang telah ditetapkan yang didukung dengan ketua yang memiliki komitmen yang tinggi dalam membina para pengurus. 


\section{DAFTAR PUSTAKA}

Afuan, M. 2021. Determinasi Kepuasan Kerja dan Komitmen Organisasi: Keadilan Distribusi dan Keadilan Interaksional (Suatu Kajian Studi Literatur Manajemen Sumber Daya Manusia). Jurnal Manajemen Pendidikan dan Ilmu Sosial. Vol. 2, Issue. 1, E-ISSN: 2716-375X, P-ISSN: 2716-3768. Pages: 331 - 346.

Arifin, Noor. 2013. Manajemen Sumber Daya Manusia Teori dan Kasus. Universitas Islam Nahdatul Ulama (UNISNU) Jepara: UNISNU PRESS

Busro, Muhammad. 2018. Teori-teori Manajemen Sumber Daya Manusia. Jakarta: Prenadamedia Group.

Haryanto, Aris Tri, Jarot Santosa \& BRM. Suryo Triono. 2020. Implementasi Motivasi, Pengembangan Sumber Daya Manusia, Komitmen, Kepuasan dan Kinerja. Jurnal ECOBISMA. Vo. 7, No. 22, P-ISSN: 2477-6092, E-ISSN: 2620-3391. Halaman: $26-39$.

Heriyanti. 2020. Pengembangan Sumber Daya Manusia Melalui Motivasi dalam Meningkatkan Kinerja Pegawai Badan Amil Zakat Nasional Kabupaten Tanjung Jabung Timur. Abstrak. Universitas Islam Negeri Sultan Thaha Saifuddin Jambi.

Hidayaturrahman, Imamulhaq Al - qur'anu \& Muhammad Shodiqin. 2015. Hubungan Loyalitas Organisasi MahasiswaTerhadap Komitmen Belajar di IAIN Antasari Banjarmasin. Banjarmasin: Pusat Penelitian dan Penerbitan, Institut Agama Islam Antasari.

Pranita, Ferum Mahendra. 2017. Influence of Motivation anda Organizational Commitment on Work Satisfaction and Employee Performance. International Consortium of Education and Culture Research Studies. ISSN: 2548-6160. Pages: $24-31$.

Sugiyanto, Samodra Kharisma Aji. 2015. Hubungan antara Kepuasan Berorganisasi dengan Komitmen Organisasi Pada Anggota Unit Bola Basket UMS. Naskah Publikasi. Universitas Muhammadiyah Surakarta.

Sunyoto, Danang. 2013. Manajemen Sumber Daya Manusia. Jakarta: CAPS.

Sutoro, M. 2020. Faktor-faktor yang Mempengaruhi Komitmen Tenaga Pengajar Perguruan Tinggi. Scientific Journal of Reflection: Economic, Accounting, Management and Business. Vol. 3, No. 1, p-ISSN: 2615-3009, e-ISSN: 2621-3389.

Utamy, Rahma, Syarwani Ahmad \& Syaiful Eddy. 2020. Implementasi Manajemen Sumber Daya Manusia. Journal of Education Research, pages: 226-236.

Yulistina. 2017. Komitmen dalam Berorganisasi Pada Mahasiswa Lembaga Pengembangan Tilawatil Qur'an dan Dakwah UIN Raden Fatah Palembang (Abstrak). Palembang: Universitas Islam Negeri Raden Fatah, Fakultas Psikologi. 